\title{
marife
}

dini araştırmalar dergisi

Turkish Journal of Religious Studies

cilt / volume: 17 • sayı / issue: $1 \bullet$ yaz / summer 2017

\section{Hz. Peygamber'in Hicret Yolunda Ümmü Ma'bed'e Uğramasıyla İlgili Rivâyet ve Davet Metodu Açısından Analizi}

\author{
Mücahit Yüksel \\ Öğr.Gör.Dr., Necmettin Erbakan Üniversitesi Ahmet Keleşoğlu İlahiyat Fakültesi \\ Arap Dili ve Belağatı Ana bilim dalı Öğretim Üyesi \\ myksl_42@hotmail.com
}

Geliş Tarihi: 06.01.2017 • Yayına Kabul Tarihi: 25.03.2017

$\ddot{O} z$

Yüce Allah, Hz. Muhammed'i insanlara örnek olarak gönderdi. Onun söz ve davranıșlarında, bizler için güzel örnekler bulunmaktadır. Hz. Muhammed, bir peygamber olarak, Yüce Allah'ın mesajlarını insanlara öğretirken birçok prensibe dikkat etmiștir. O, öğrettiği ilkeleri önce kendisi uygulamıștır. Bu sebeple Hz. Peygamber'in söyledikleri ile yaptıkları arasında bir çelişki görülmemiştir. O, peygamberlik görevini yerine getirirken dış görünümüne de özen göstermiştir. Yani Hz. Muhammed, maddî ve manevî özellikleriyle birlikte örnek bir davetçi profili sergilemiștir. Onun bu konuda gösterdiği bașarının ardından, kısa süre içinde birçok insan Müslüman olmuştur. Böylece örnek bir toplum ortaya çıkmıştır. Söz ve davranış, tebliğ sürecinde muhatabı etkileyen önemli unsurlardır. Fakat davranış bu noktada daha ön plandadır. Zira eylemlerle desteklenmeyen sözlerin etkisi de zayıftır. Her firsatta Allah'ın (c.c.) dinini tebliğ etmek için çaba harcayan Hz. Peygamber, hicret esnasında uğradı̆̆ı Ümmü Ma'bed'in çadırında da söz ve davranışlarıyla muhatabını etkilemiștir. Bu makalede, Ümmü Ma’bed rivâyeti üzerinden, davetçinin dikkat etmesi gereken hususlar ele alınmaktadır.

Anahtar kelimeler : Hz. Muhammed, Ümmü Ma'bed, Tebliğ, Davetçi, Hicret.

Rumor about Hz. Muhammad's visit to Ummu Mabed in the way of Hegira and Its analysis in terms of invitation method

Almighty Allah sent Muhammad as an example to people. In his words and deeds, there are good examples for us. Hz. Muhammed as a prophet, paid attention to many principles when he taught people the messages of Almighty Allah. He practiced the principles he taught himself first. For this reason There is no contradiction between what the Prophet said and what he did. He also took care of his appearance while he fulfilled his prophetic duty. So Hz. Muhammad exhibited an exemplary invitation profile with his material and spiritual attributes. Following his success, many people became Muslims in a short period of time. Thus, a representative society emerged. The speech and the behavior are the important factors which impact of adresse in the process transmission. But the behavior is the highlights in this stage. So The impact of the speechs which be unsupported with actions is weak. At every opportunity the respected prophet which he effort for transmission of Allah's religion had effect of his adresse with his the speechs and the behaviors in Ummu Ma'bed's tent during migration in this article. The subjects which the calling must be careful based on Ummu Ma'bed's rumor is discussed.

Keywords: Hz. Muhammed, Ummu Ma'bed, Transmission, Calling, Migration..

Atıf

Yüksel, Mücahit, “Hz. Peygamber'in Hicret Yolunda Ümmü Ma'bed’e Uğramasılyla İlgili Rivâyet ve Davet Metodu AçısındanAnalizi”, Marife, 17/1(2017): 137-150. 


\section{Giriş}

Hz. Peygamber'in Mekke'den Medine'ye yapmış olduğu hicret, İslâm tarihi kaynaklarında ayrıntılı şekilde anlatılmaktadır. Ancak bu yolculuk esnasında çadırına uğradığı Ümmü Ma’bed ve onunla arasında geçen diyalog, yeteri kadar gündeme gelmemiştir. Halbuki bu esnada Rasûlullah'ın yaptıkları ve söyledikleri, İslâm'a çağırırken insanları etkileyebilmek için dikkat edilmesi gereken önemli mesajlarla doludur. Olayı anlatan rivâyetler incelendiği zaman, muhatap durumunda olan Ümmü Ma'bed'in bizzat kendi ağzından, veciz bir şekilde bu özelliklerin ifade edildiği görülmektedir.

İnsanların hidâyetine vesile olmanın istek ve gayretinde olan davetçilere yol gösterici bir fonksiyon icra ettiğine inandığımız bu rivâyete ve muhtevasından çıkarılabilecek ilkelere vurgu yapmanın önemine inandığımız için böyle bir makâle yazmayı uygun gördük. Bu kapsamda ilk olarak, olayın kahramanlarından olan Ümmü Ma'bed'in kısaca tanınması uygun olacaktır.

\section{1. Ümmü Ma'bed'in Kişiliği}

Klasik İslâm tarihi kaynakları incelendiği zaman, Ümmü Ma’bed hakkında ayrıntılı bilgilerin mevcut olmadığı görülmektedir. Onun, tarih sahnesinde adının geçtiği fazlaca bir olaya da rastlanmamaktadır. Bu sebeple kişiliğiyle ilgili bilgiler, genellikle konumuza temel teşkil eden rivâyet ekseninde dönmektedir.

Adı, Âtike binti Hâlid b. Huleyf el-Huzâî ${ }^{1}$, künyesi ise Ümmü Ma'bed'dir. ${ }^{2}$ Huzaâ'nın Benî Ka’b kabilesine mensûptur. ${ }^{3}$

Eksem İbnü'l-Cevn (Abduluzzâ) b. Munkîz el-Huzâî ile evli olan Ümmü Ma'bed $^{4}$, kocasıyla birlikte Mekke ile Medine arasındaki Kudeyd köyünde yaşıyordu. ${ }^{5}$

Çok cömert bir insan olan Ümmü Ma’bed, çadırının önünde oturur, gelenlere su ve yemek ikram ederdi. ${ }^{6}$ Müşrikler tarafından uygulanan işkenceler artıp, Mekke yaşanmaz hâle gelince Hz. Ebû Bekir ile birlikte hicret eden Hz. Peygamber

1 Belâzurî, Ahmed b. Yahyâ b. Câbir b. Dâvud, Cümel min ensâbi'l-eşrâf, 1. Baskı, thk: Süheyl Zekkâr, Riyâd ez-Ziriklî, Dâru'l-Fikr, Beyrut 1996, I, 262; Şeybânî, Ebûbekir b. Ebî Âsım, Ahmed b. Amr b. Dahhâk, el-Âhâd ve'l-mesânî, 1. Baskı, thk: Bâsim Faysal Ahmed el-Cevâbira, Dâru'r-Râye, Riyâd 1991, VI, 252; İbn Abdilberr, Ebû Ömer Yusuf b. Abdullah b. Muhammed, el-İstîâb fî ma'rifeti'l-ashâb, 1. Baskı, thk: Ali Muhammed el-Bicâvî, Dâru'l-Cîl, Beyrut 1992, IV, 1876.

2 Beğavî, Ebû Muhammed el-Hüseyn b. Mes'ûd b. Muhammed, Şerhu's-Sünne, 2. Baskı, thk: Şuayb elArnaût, Muhammed Züheyr eş-Şâvîș, el-Mektebü'l-İslâmî, Dımașk, Beyrut 1983, XIII, 261.

3 İbn Hişâm, Ebû Muhammed Cemâluddin, es-Sîratü'n-nebeviyye, 2. Baskı, thk: Mustafa es-Sakâ, İbrahim el-Ebyârî, Abdulhafîz eș-Şelebî, Matbaatu Mustafa el-Bâbî el-Halebî ve Evlâduhû, Mısır 1955, I, 487.

${ }^{4}$ Belâzurî, Cümel, I, 262; Neysâbûrî, Abdulmelik b. Muhammed b. İbrahim el-Harkûşî, Şerefu'l-Mustafa, 1. Baskı, Dâru'l-Beşâiri'l-İ́slâmiyye, Mekke 1424h., II, 355.

5 İbn Sa'd, Ebû Abdullah Muhammed b. Sa'd b. Munî', et-Tabakâtu'l-kübrâ, 1. Baskı, thk: Muhammed Abdülkadir Atâ, Dâru'l-Kütübi'l-İlmiyye, Beyrut 1990, VIII, 224; İbn Abdilberr, el-İstîâb, IV, 1958; Eren, Mehmet, “Ümmü Ma’bed”, DİA, İstanbul 2012, XLII, 325.

${ }^{6}$ Neysâbûrî, Şerefu'l-Mustafa, II, 355. 
de onun çadırına uğramış ve yanındakilerle birlikte Ümmü Ma'bed'ten et ve hurma

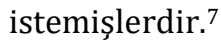

Ümmü Ma'bed, daha sonra hicret etmiş, Müslüman olmuş ve Rasûlullah'ın (s.a.v.) yanına gelmiștir. ${ }^{8}$ Sahâbi olma șerefine nâil olan Ümmü Ma'bed'in vefat tarihine dâir net bir bilgi mevcut değildir.

\section{Hicret Esnasında Rasûlullah (s.a.v) ile Diyaloğunu Anlatan Rivâyet}

Ümmü Ma'bed'in Hz. Peygamber'le karşılaşması olayı ile ilgili olarak, onun kardeşi Hubeyş, kocası Ebû Ma‘bed, Selît el-Ensârî, Câbir b. Abdullah, Esmâ binti Ebû Bekir ve Ebû Bekir es-Sıddîk tarafından nakledilen rivâyetler bulunmaktadır.

Bu rivâyetler incelendiği zaman, çok küçük bazı farklar bulunmakla birlikte olayın şu şekilde gerçekleştiği görülmektedir: "Ümmü Ma'bed anlatıyor: "Rasûlullah (s.a.v.) Mekke'den hicret edip, yanında Ebû Bekir Sıddîk, onun anlaşmalı kölesi olan Âmir b. Füheyre ve rehberleri olan Abdullah b. Uraykıt el-Leysî ile birlikte Medine'ye doğru yola çıktığı zaman bize uğradılar ve çadırıma girdiler. Ben, çadırımın havlusunda ellerimi çemreleyerek oturur, oradan gelip geçenlerin karnını doyurup su ikram ederdim. Rasûlulllah, et ve hurma bulunup bulunmadığını sordu. Bunun üzerine ben, "Hayır vallahi, eğer istediğiniz șey bende olsaydı sizi ağırlamaktan çekinmezdim." dedim. Bu arada Rasûlullah, çadırın bir köşesinde oturmakta olan bir keçiyi gördü ve: "Ey Ümmü Ma'bed! Bu keçiye ne diyorsun?" diye sordu. Ben de: "Vallahi, bu zavallı keçi zayıf ve çelimsiz olduğu için başka keçilerle beraber otlamaya gidemedi." dedim. Hz. Peygamber (s.a.v): "İzin verir misin? ona yaklaşsak da süt sağsak" dedi. Ben de: "Anam-babam size feda olsun. Ĕger onda birazcık süt bile varsa memnuniyetle sağabilirsiniz." dedim. Bunun üzerine Rasûlullah keçiyi yanına getirtti ve memelerine mübarek elini sürdü. Sonra besmele çekti ve keçiye bolca süt ihsan etmesi için Allah'a dua etti ve Allah'ın adıyla süt sağmaya başladı. Allah'ın lütfuna bakın ki, keçi ayaklarını açtı ve bir yandan da memelerinden pınar gibi süt fışkırmaya başladı. Rasûlullah bir kova getirtti. Ben de kovayı getirdim. Kova bir kaç kişiyi doyurmak için süt alacak büyüklükte idi. Rasûlullah, süt sağmaya devam etti, tâ ki kova doldu ve üstünde köpükler belirdi. Rasûlullah bu sütten, bana içirdi ve ben doydum. Bundan sonra sütü Ebû Bekir'e ve diğer arkadaşlarına verdi ve onlar da doydular. En son Rasûlullah içti ve yanındakilerle birlikte ayrıldı. Sonra kocam, keçilerimizi güttüğü yerden geldi ve ona sütü getirdim. Ardından da Rasûlullah'tan ve bereketinden bahsettim. Bunun üzerine benden, onun özelliklerini anlatmamı istedi. Ben de anlattım: "Karakteri temiz, yüzü parlak, güzel ahlakl, mütebessim, ne şişmandı ne de zayıf. Çok güzel yüzlü ve çekiciydi. Gözlerinde siyah derinlikler vardı. Kirpikleri uzundu. Sesi yüksekti ama sert değildi. Boynu sanki ay gibiydi, sakalı gürdü. Kalem kaşlıydı. Sessizken vakar ve metanetin bir simgesiydi. Konuşurken de etrafa hâkim olurdu. Uzaktan dinlendiğinde sesi herkese hâkim ve

7 Bu sırada Ümmü Ma’bed ile Rasûlullah (s.a.v.) arasında geçen diyalogla ilgili rivâyetin tamamı bir sonraki başlıkta zikredilecektir.

${ }^{8}$ Isfahânî, Ebû Nuaym Ahmed b. Abdullah, Delâilü'n-nübüvve, 2. Baskı, thk: Muhammed Ravâs Kal'acî, Abdulberr Abbâs, Dâru'n-Nefâis, Beyrut 1986, I, 337. 
kulağa hoş gelirdi. Yakından dinlendiğinde ise çok şirin ve yumuşaktı. Konuşması tatlı ve gevezelikten uzaktı. Konuştuğu zaman, inci ve mercan gibi düzgündü, ne az ne de çok idi. Orta boyluydu. Aşırı uzun boylu görülmeyecek kadar boyluydu. Boyu kısa da değildi ki, yanında insanın dikkati başkasına çekilsin. Arkadaşlarının en hoş görünümlü ve hoş sohbetlisiydi; aynı zamanda herkesten daha muhterem ve hürmete lâyıktı. Oturduğu zaman etrafindakiler ona hürmet ediyor, konuştuğu zaman susuyorlar ve kalktı̆̆ı zaman da kalkıp etrafinda duruyorlardı. Arkadaşları, etrafinda pervane gibiydiler. Sözlerine kulak kabartıyor ve söylediklerini derhal yerine getiriyorlardı. Allah'ın nurundan dolayı kavmi Ona haset ediyordu. O, ası suratlı değildi ve sözleri de kaba veya sert değildi. Ínsanların en temiz ahlaklısı idi." Bunun üzerine eşim bana şöyle dedi: "Bu, bana durumu Mekke'de anlatılan Kureyş'in sahibidir. Ona gelip arkadaş olmayı çok istedim. Eğer buna bir yol bulursam bunu yapacă̆ım İnşaallah."”9

Ümmü Ma'bed bu sırada bir ses duyduklarını ifade etmektedir. Buna göre, Rasûlullah (s.a.v.) ve arkadaşlarının Ümmü Ma'bed'e uğradığından haberdar olan yabancı bir adam şu beyitleri dillendirmektedir:

“İnsanların Rabb'ı, Ümmü Ma'bed'in iki çadırına yerleșen iki arkadaşı mükafâtlandırdı.

Onlar orada konakladılar, istirahat ettiler ve Muhammed'in arkadaşı olan kişi kurtuluşa erdi.

Ka'b oğullarının genç kadınının yeri, müminler için bir istirahat yeri, bir gözetleme yeri olarak mübarek olsun." 10

Aynı olayın farklı bir boyutunu ise Esmâ binti Ebû Bekir şöyle anlatmaktadır:

"Rasûlullah (s.a.v) ve Ebû Bekir çıktıkları zaman, içlerinde Ebû Cehil'in de bulunduğu Kureyşli bir grup bize geldi. Nereye gittiklerini sordu, bilmediğimi söyledim, bunun üzerine yanağıma tokat attı. Üç gün böyle geçti. Daha sonra Mekke'nin aşağı tarafından tanınmamış bir adam, söylediği beyitle onların Ümmü

9 Şeybânî, el-Âhâd ve'l-mesânî, VI, 252. Konuyla ilgili rivâyetleri karşılaştırmak için ayrıca bk: Bezzâr, Ebûbekir Muhammed b. Abdullah b. İbrahim, Kitâbu'l-fevâid, 1. Baskı, Hilmî Kâmil Esad Abdulhâdî, Dâru İbni'l-Cevzî, Riyâd 1997, II, 829; Âcurrî, Ebûbekir Muhammed b. Hüseyin b. Abdullah, eş-Şerîa, 2. Baskl, thk: Abdullah b. Ömer b. Süleyman ed-Demîcî, Dâru'l-Vatan, Riyâd 1999, III, 1496; Neysâbûrî, Şerefu'l-Mustafa, II, 357; Beğavî, Șerhu's-Sünne, XIII, 262; İbnü'l-Esîr, İzzuddin, Üsdü'lgâbe fî̀ ma'rifeti's-Sahâbe, 1. Baskı, thk: Ali Muhammed Muavvid, Âdil Ahmed Abdulmevcûd, Dâru'lKütübi'l-İlmiyye, Beyrut 1994, VII, 180, 387; Zehebî, Şemsuddin Ebû Abdullah, Siyeru a'lâmi'nnübelâ, 3. Baskı, thk: Şuayb el-Arnâût vd., Müessesetü’r-Risâle, Beyrut 1985, II, 373-376; Makrızî, TakıyuddinAhmed b. Ali b. Abdulkâdir, İmtâu'l-esmâ' bimâ li'n-Nebî mine'l-ahvâl ve'l-emvâl ve'lhafede ve'l-metâ', 1. Baskı, thk: Muhammed Abdulhamid en-Nemîsî, Dâru'l-Kütübi'l-İlmiyye, Beyrut 1999, I, 61, II, 176-177; İbn Hacer el- Askalânî, Ebu'l-Fadl Ahmed b. Ali, el-İsâbe fî temyîzi's-Sahâbe, 1. Baskl, thk: Âdil Ahmed Abdulmevcûd, Ali Muhammed Muavvid, Dâru'l-Kütübi'l-İlmiyye, Beyrut 1415h., VIII, 475-477; Suyûtî, Abdurrahman b. Ebûbekir Celaluddin, el-Hasâisu'l-kübrâ, Dâru'lKütübi'l-İlmiyye, Beyrut, ty., I, 309-311.

10 İbnü'l-Cevzî, Cemaluddin Ebu'l-Ferec Abdurrahman b. Ali b. Muhammed, el-Muntazam fî tarihi'lümem ve'l-mulûk, 1. Baskl, thk: Muhammed Abdulkâdir Atâ, Mustafa Abdulkâdir Atâ, Dâru'lKütübi'l-İlmiyye, Beyrut 1992, III, 59; Zehebî, Târihu'l-İslâm ve vefeyâti'l-meşâhîr ve'l-a'lâm, 2. Baskl, thk: Ömer Abdüsselam et-Tedmurî, Dâru'l-Kitâbi'l-Arabî, Beyrut 1993, I, 437-439. 
Ma'bed'in yanına gittiğini söyledi. Duyduğumuzda dört kişi olarak Medine’ye yöneldiklerini anladık."11

Kureyș, bağıran yabancıyı duyduğu zaman bazı kişileri Ümmü Ma'bed'e gönderdiler. Bu kișiler Ümmü Ma'bed'e: “Şu şu özellikteki Muhammed sana uğradı mı?" diye sordular. 0 da: "Sizin neyi kasteddiğinizi bilmiyorum, ancak bana koyunu sağan birileri misafir oldu. Dört kişiydiler."12 diyerek onları başından savmıştır.

Hâkim'in de Müstedrek'inde zikrettiği bu olayla ilgili rivâyet, Buhârî ve Müslim'in tahric etmediği sahih bir hadistir. ${ }^{13}$

\section{Tebliğ Metodu Açısından Rivâyetin Analizi}

İnsanları etkilemenin birçok yolu vardır. Bu konuda en çok öne çıkarılan başlık ise hitâbettir. Fakat realiteye bakıldığı zaman insanların, sözden ziyade davranışlardan etkilendiği görülmektedir. Elbette en güzeli ise, söz ve davranış bütünlüğü içinde muhataba yönelmektir. Bu takdirde muhatapta birakılacak olan etki de daha kuvvetli olacaktır. Her konuda olduğu gibi tebliğ konusunda da en güzel örnekleri Hz. Peygamber'de görmekteyiz. Nitekim Allah Teâlâ, "Gerçekten Allah'ın Rasûlünde sizin için güzel bir örnek vardır..."14 buyurmaktadır. Rasûlullah'ın (s.a.v.) Medine'ye hicret esnasında çadırına uğradığı Ümmü Ma'bed karşısında sergilediği davranış ve diyalog örnekleri de bu anlamda davetçilere güzel örnekler sunmaktadır. Çalışmamızın bu bölümünde, mezkûr rivâyette öne çıkan davet ilkeleri üzerinde durulacaktır.

\subsection{Davetçi kişisel bakımına özen göstermelidir}

Rivâyette Rasûlullah'ın özelliklerini sayan Ümmü Ma'bed, onun hem fizikî, hem de ahlâkî ilkelerini saymaktadır. Bu çerçevede onun fizikî özellikleri için şu ifadelere yer verdiğine şahit olunmaktadır: "Yüzü parlak, ne şişmandı ne de zayıf. Çok güzel yüzlü ve çekiciydi. Gözlerinde siyah derinlikler vardl. Kirpikleri uzundu. Sesi yüksekti ama sert değildi. Boynu sanki ay gibiydi, sakalı gürdü. Kalem kaşlıydı. Orta boyluydu. Aşırı uzun boylu görülmeyecek kadar boyluydu. Boyu kısa da değildi ki, yanında insanın dikkati başkasına çekilsin. Arkadaşlarının en hoş görünümlüsüydü"

Her ne kadar Hz. Peygamber hoş görünümlü bir insan olsa da, elbette insanların fizikî görünümleri, kendi ellerinde olan bir husus değildir. Allah Teâlâ kimi kullarını güzel, kimi kullarını da çirkin yaratmaktadır. Bu husus, bir övgü ya da yergi konusu da yapılamaz. Zira Allah Teâlâ, dış güzelliğe değil, iç güzelliğe itibar etmektedir. Ancak insan her ne kadar kendi fizikî özelliklerini seçemese de kişisel bakımına dikkat ederek belli ölçüde ilerleme kaydedebilmektedir. Bu husus

11 Taberî, Muhammed b. Cerîr, Tarühu'l-ümem ve'l-mulûk, 1. Baskl, Dâru'l-Kütübi'l-İlmiyye, Beyrut 1407, I, 570.

12 Süheylî, Ebu'l-Kâsım Abdurrahman b. Abdullah, er-Ravdu'l-unuf fî șerhi's-sîreti'n-nebeviyye li'bni Hişâm, 1. Baskı, thk: Ömer Abdusselâm es-Selâmî, Dâru İhyâi't-Turâsi'l-Arabî, Beyrut 2000, IV, 145.

${ }^{13}$ Hâkim en-Nîsâbûrî, Ebû Abdillâh Muhammed b. Abdillâh b. Muhammed, el-Müstedrek ale's-Sahîhayn, 1. Baskl, thk: Mustafa Abdulkâdir Atâ, Dâru'l-Kütübi'l-İlmiyye, Beyrut 1990, III, 10.

${ }^{14}$ Ahzâb 33: 21. 
tebliğ açısından da önemlidir. Çünkü her ne kadar iç bakım ve iç güzellik, kalıcı etki açısından önemliyse de dış bakım ve dış güzellik de ilk etki açısından önemlidir.

Allah Teâlâ, peygamberini tebliğ ile görevlendirdiği Müddessir sûresinde şöyle buyurmaktadır: "Ey bürünüp sarınan (Rasûlüm)! Kalk ve (insanları) uyar. Sadece Rabb'ini büyük tanı. Elbiseni tertemiz tut. Kötü şeyleri terk et. Yaptığın iyilikleri çok görerek başa kakma. Rabbinin rıasına ermek için sabret."15

Görüldüğü üzere mezkûr âyetlerde iç temizlik ile birlikte dış temizliğin de önemine dikkat çekilmektedir.

Hz. Peygamber'in söz ve davranışlarında da aynı hassasiyet göze çarpmaktadır. Zira Peygamber Efendimiz, günlük hayatında yanında "sükke" tabir edilen bir koku bulundurur ve gerektikçe ondan sürünürdü. ${ }^{16}$ Yine bir başka rivâyete göre Rasûlullah (s.a.v.) saçı dağınık bir adam gördüğü zaman, "Bu adam saçlarını düzeltecek bir şey bulamadı mı?” demiştir. Elbisesi kirli başka bir adama da "Bu adam elbisesini yıkayacak su bulamadı mı?" demiștir. ${ }^{17}$ Ayrıca Rasûlullah (s.a.v.), Hz. Âişe'nin rivayet ettiği bir Hadîs-i Şerif'te de şöyle buyurmaktadır: "On şey fitrattandır: Bıyığın kesilmesi sakalın uzatılması, misvak, istinşak (burna su çekmek), mazmaza (ağza su çekmek), tırnakları kesmek, parmak mafsallarını yıkamak, koltuk altını yolmak, etek traşı olmak, intikasu'l-ma yani istinca yapmak."18

Netice itibariyle tebliğ görevini ifa eden kişinin ahlâkî özelliklerinin yanında dış görünümü de muhatabı etkileyen bir husustur. Çünkü temiz ve bakımlı bir dış görünüș insanları cezbederken, özensiz ve bakımsız bir dış görünüş ise insanların uzaklaşmasına sebep olmaktadır.

\subsection{Davetçi duayı bırakmamalı}

Davet, zor ve sabır gerektiren bir iştir. Çünkü ilk insanın yaratılışından itibaren süregelen hak-batıl mücadelesinde hak tarafını seçip, yüce değerleri yayma gayretinde olan insanlar, bu değerlere düşman olan batılın temsilcileri tarafından daima tepki görmüşler ve bu tepkilerin boyutu zaman zaman öldürmeye kadar varabilmiştir.

Bu noktada, tevekkülün gereği olarak elinden geleni yapmakla yükümlü olan davetçinin duayı da ihmal etmemesi gerekmektedir. Çünkü mütevazı olan bir mü'min, daima aciz olduğunun, Allah Teâlâ'nın yardımına muhtaç olduğunun ve gelen başarının da O'nun lütfuyla geldiğinin farkındadır. Zira Yüce Allah Alak Sûresi'nin ilk beş âyetinde şöyle buyurmaktadır:

"Yaratan Rabbinin adıyla oku! O, insanı bir aşılanmış yumurtadan yarattı. Oku! Rabbin, en büyük kerem sahibidir. O Rab ki kalemle (yazmayı) öğretti. Insana bilmedikleri șeyi öğretti."19

\footnotetext{
15 Müddessir 74: 1-7.

${ }^{16}$ Ebû Dâvûd, Teraccül 2, (4162).

17 Ebû Dâvûd, Libâs 17, (4062).

18 Müslim, Hısâlu'l-Fitrat 56.

${ }^{19}$ Alak 96: 1-5.
} 
Unutmamak gerekir ki bizi Allah katında değerli kılan şey dualarımızdır. Çünkü Yüce Allah, Furkan Sûresi'nde, "(Resulüm!) De ki: "Rabbim size ne klymet verir duanız olmasa?" buyurmaktadır. ${ }^{20}$

Nasıl dua edileceğine dair, hayatında en güzel örnekleri sunan $\mathrm{Hz}$. Peygamber ise bu hususta, "Büyük zorluklara dûçar olduğunuz zaman "Allah bize yeter. 0 ne güzel vekildir" deyiniz."21 buyurmuştur. Kendisi de, "Allah'ım, üzüntüden ve kederden sana sığınırım." 22 diyerek dua etmiştir.

Ancak unutmamak gerekir ki dua, sadece sıkıntılı anlarda ihtiyaçların karşılanması için değil, rahat anlarda da şükür için başvurulacak bir yoldur. İnsanların bu noktadaki zaafını ise Allah Teâlâ şöyle ifade etmektedir:

"İnsana bir sıkıntı dokunduğu zaman, gerek yan yatarken, gerek otururken, gerek dikilirken bize dua eder. Kendisinden sıkıntısını gideriverdik mi sanki kendisine dokunan o sıkıntı için bize hiç yalvarmamış gibi aldırmadan geçer gider. Isşte o aşırı gidenlere yaptıkları şeyler böyle güzel gelir."23

\subsection{Davetçi asalak mizaçlı olmamalıdır}

Rasûlullah'ın, Ümmü Ma'bed'den istediklerini karşılıksız değil, ücret mukabilinde istediği görülmektedir. Onun bu davranışında da tebliğci açısından önemli bir ilke bulunmaktadır. Zira davetçinin eli açık olması ve cimrilikten uzak durması, muhatabı olumlu yönde etkileyen bir özelliktir. Bu konuda Yüce Allah şöyle buyurmaktadır:

“Allah'ın, kendilerine lütfundan verdiği nimetlere karşı cimrilik edenler, bunun kendileri için hayırlı olduğunu sanmasınlar. Hayır o, kendileri için şerdir. Cimrilik ettikleri şey, klyamet gününde boyunlarına dolanacaktır. Göklerin ve yerin mirası Allah'a aittir. Allah yaptıklarınızdan haberdardır."24

Rasûlullah (s.a.v.) ise şöyle buyurmaktadır: "İki haslet vardır ki bir mü'minde asla beraber bulunmazlar: Cimrilik ve kötü ahlâk. "25 Abdullah İbnu'ş-Şihhîr (R.A.) anlatmaktadır: "Rasûlullah (s.a.v.) Elhâkümü'ttekâsür sûresini okurken yanına geldim. Bana: "İnsanoğlu malım malım der. Halbuki âdem-oğlunun yiyip tükettiği, giyip eskittiği ve sağlığında tasadduk edip gönderdiğinden başka kendisinin olan neyi var? (Gerisini ölümle terkeder ve insanlara bırakır." 26

Davetçi, insanlar arasında kendisini cimri olarak tanıtmamalı, yeri geldikçe harcamalar yapmaktan kaçınmamalı ve mümkün mertebe hediyeleşme ve ikram yoluna gitmelidir.

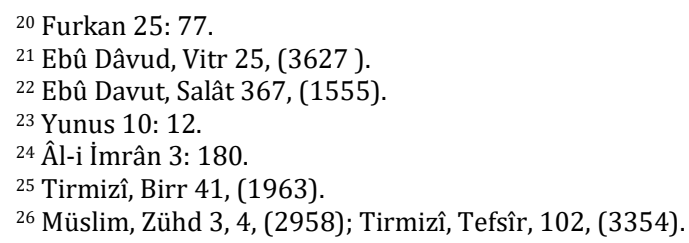




\subsection{Davetçi temiz karakterli ve güzel ahlaklı olmalıdır}

Hz. Peygamber, nübüvvetle görevlendirilmeden önce dahi çevresi tarafından takdir edilen temiz bir karaktere sahip idi. Yaşlıların itibar gördüğü bir toplumda o, genç yaştayken itibar görmeyi başarmış ve "el-Emîn" lakabına layık görülmüştür. Zira Ka'be'nin yeniden inşası sonrasında Haceru'l-Esved'i yerine koyma konusunda yaşanan kargaşada herkes onun hakemliğini rahatlıkla kabul etmiș ve verdiği karardan memnun olmuștur. ${ }^{27}$

Onun güzel ahlakını Yüce Allah ise, "Sen elbette yüce bir ahlak üzeresin."28 âyetiyle övmüştür. Kendisi ise bir hadisinde, "Ben ancak güzel ahlakı tamamlamak için gönderildim." ${ }^{29}$ buyurmaktadır.

Hz. Peygamber, davasına da bağlı bir insandı ve bu konuda hiçbir zaman taviz vermemiştir. Nitekim kendisini menfaâtle kandırmaya çalışan Mekke müşriklerine karşı sağlam bir duruş sergilemiş ve teklifi kendisine getiren amcasına, "Ey amca! Vallahi bu dâvâyı bırakmam için güneşi sağ elime, ayı da sol elime verseler yine de vazgeçmem. Allah bu dini ya hâkim kllar ya da ben bu uğurda ölürüm." șeklinde cevap vermiștir. ${ }^{30}$

Hz. Peygamber'in düzgün karakterinin bir diğer tezahürü de doğruluğu olmuştur. 0 , doğruluğu, parçalayıcı bir mantıkla ele alıp sadece "doğru konuşmak" şeklinde değerlendirmemiş, aksine söz ve eylem birliği şeklinde anlamış ve hayatına bu şekilde yansıtmıştır. Ümmetine söylediklerini önce kendisi uygulamış ve söylediklerini, davranışlarıyla yalanlamamıștır. $\mathrm{Bu}$ sebeple,"Öyle ise emrolunduğun gibi dosdoğru ol."31 âyeti onu başka türlü etkilemiştir.

Netice itibariyle günümüz davetçisi de söz ve davranışlarıyla muhatabına güven vermeli ve insanlara söylediklerini öncelikle kendisi uygulamalıdır. Aksi takdirde söylediklerinin etkisi az olacaktır.

\subsection{Davetçi mütebessim olmalıdır}

Ümmü Ma'bed'in, Rasûlullah'ı anlatırken belirttiği özelliklerinden birisi de onun, asık suratlı değil mütebessim oluşudur. İnsanlar arası ilişkilerdeki önemli hususlardan birisi de güler yüzlü olmaktır. Çünkü güler yüz ya da asık surat, fazla tanınmayan insanlar hakkında ilk etapta sempati ya da antipati oluşmasına sebep olmaktadır.

Bu konu Hz. Peygamber'in söz ve davranışlarında da fark edilir şekilde kendisini göstermiş, hatta bir sadaka olarak ifade edilmiștir:

\footnotetext{
27 İbni İshâk, Muhammed b. İshâkb. Yesâr el-Muttalibî, Sîretu İbni İshâk, 1. Baskı, thk: Süheyl Zekkâr, Dâru'l-Fikr, Beyrut 1978, s. 108; İbn Hişâm, es-Sîretü'n-nebeviyye, I, 183.

${ }^{28}$ Kalem 68: 4.

${ }^{29}$ Beyhakî, Mekârimu'l-Ahlâk, 20782.

30 İbni İshâk, Sîret, s. 154; İbn Hişâm, es-Sîretü'n-nebeviyye, I, 266.

31 Hûd 11: 112.
} 
"Kardeșine tebessüm etmen sadakadır. İyiliği emredip kötülükten sakındırman sadakadır. Yolunu kaybeden kimseye yol göstermen sadakadır. Yoldan taş, diken, kemik gibi şeyleri kaldırıp atman da senin için sadakadır."32

Ayrıca Hz. Peygamber, "Hayrı, iyiliği güzel yüzlü olanların yanında arayınız!"33 sözüyle, iyi insanların güler yüzlü olması gerektiği ve güler yüzlü insanların, iyilik ehli olduğu gerçeğini de ifade etmiştir.

Ancak burada dikkat edilmesi gereken husus ise, tebessüm ile gülmeyi birbirine karıştırmamaktır. Çünkü Hz. Peygamber'de görülen ve muhatabı olumlu yönde etkileyen özellik tebessümdür. Çok gülmek ise davetçinin ciddiyetini zedeleyen bir husustur. Ayrıca Hz. Peygamber bu hususta, "Çok gülmek kalbi öldürür."34 buyurmaktadır.

\subsection{Davetçi nerede ne kadar konuşacağını bilmelidir}

Ümmü Ma'bed, Rasûlullah'ı anlatırken ayrıca şu ifadelere yer vermektedir: "Sessizken vakar ve metanetin bir simgesiydi. Gevezelikten uzaktı. Konuşurken de etrafa hâkim olurdu."

Davetçinin dikkat etmesi gereken diğer bir husus ise, konuşma esnasında basitlikten kaçınmak, vakur bir edâ takınmak ve gevezelik türünden sözleri terk etmek suretiyle mesajı özlü bir şekilde ifade etmektir. Bu hususta örnek alacağımız Hz. Peygamber kendisi hakkında,"Ben, cevâmiu'l-kelim olarak gönderildim."35 buyurmuştur.

Ayrica Hz. Peygamber, her zaman konuşma gayretine girmez karşısındakilerin dinlemeye istekli olup olmadığını da dikkate alırdı. Onun bu konudaki hassasiyetini Abdullah b. Mes'ud (R.A.) şöyle anlatmaktadır: "Ashabı usanıp sıkılır düşüncesiyle Hz. Peygamber, bize her gün değil, ara sıra vaaz ve nasihat ederdi." 36

$\mathrm{Bu}$ sebeple davetçi, devamlı surette konuşmak için bir yol aramamalı, her ânı fırsat görüp konuşmamalı ve eğer bir faydası olmayacaksa sözlerini uzatmaktan kaçınmalıdır. Çünkü önemli olan senin ne kadar söylediğin değil, karşıdakinin ne kadar anladığıdır.

\subsection{Davetçi konuşma üslubuna dikkat etmelidir}

Ümmü Ma'bed, Hz. Peygamber'in konuşma üslubunu ise, “Uzaktan dinlendiğinde sesi herkese hâkim ve kulağa hoş gelirdi. Yakından dinlendiğinde çok şirin ve yumuşaktı. Kaba ve sert değil, hoş sohbetliydi." sözleriyle ifade etmektedir.

\footnotetext{
32 Tirmizî, Birr, 36, (1956).

33 İbni Hanbel, Ebû Abdullah Ahmed b. Muhammed, Fadâilu's-Sahâbe, 1. Baskı, thk: Vasiyullah Muhammed Abbâs, Müessesetü'r-Risâle, Beyrut 1983, II, 726; Ebû Ya'lâ, Ahmed b. Ali b. Müsennâ b. Yahyâ, Müsned-i Ebî Ya'lâ, 1. Baskı, Hüseyin Selim Esed, Dâru'l-Me'mûn li't-Turâs, Dımaşk 1984, VIII, 199.

34 İbni Mâce, Zühd, 19.

35 Buhârî, Cihad, 122.

${ }^{36}$ Buhârî, Menâkıb, 23; İlim, 30.
} 
Atalarımızın da belirttiği gibi, tatlı söz yılanı deliğinden çıkarır. Bu sebeple konuştuğumuz sözlerin doğru ve güzel olmasının yanında, tatlı bir üslupla muhataba sunulması da önemlidir. Çünkü muhataba değer vermeyen ve rencide eden bir üslup, onun kaçmasına ve mesajın ulaşamamasına sebep olur. Bu konuda Allah Teâlâ, "Rabb'inin yoluna hikmetle, güzel ögütle davet et ve onlarla en güzel şekilde mücadele et..."37 buyurmaktadır. Hz. Peygamber ise, "Kolaylaştırınız, zorlaştırmayınız, müjdeleyiniz, nefret ettirmeyiniz!"38 buyurarak iletişimde üslubun önemine dikkat çekmektedir.

Bunun aksi bir tutumun yol açacağı hususu ise Yüce Allah şu şekilde belirtmektedir:

“O vakit Allah'tan bir rahmet ile onlara yumuşak davrandın! Şayet sen kaba, katı yürekli olsaydın, hiç şüphesiz, etrafından dağılıp giderlerdi. Şu hâlde onları affet; bağışlanmaları için dua et; iş hakkında onlara danış. Kararını verdiğin zaman da artık Allah'a dayanıp güven. Çünkü Allah, kendisine dayanıp güvenenleri sever."39

\subsection{Davetçi, hürmete layık bir konumda olmalıdır}

Ümmü Ma'bed hadisinde dikkat çeken diğer bir durum da, Hz. Peygamber'in yanında bulunan arkadaşlarının, ona gösterdiği hürmettir. Bu husus da Ümmü Ma'bed'in dikkatini çekmiş ve durumu şu şekilde ifade etmiştir: "Oturduğu zaman etrafindakiler ona hürmet ediyor, konuştuğu zaman susuyorlar ve kalktığı zaman da kalkıp etrafında duruyorlar. Arkadaşları etrafinda pervane gibiydiler. Sözlerine kulak kabartıyor ve söylediklerini derhal yerine getiriyorlardı. Allah'ın nurundan dolayı kavmi ona haset ediyordu."

Gerçekten de davetçinin etrafında bulunan ve onu tanıyan insanların ona gösterdiği saygı ve hürmet de onun sözünün etkisini artıran hususlardandır. Çünkü kendi etrafındaki insanlar tarafından saygı görmeyen bir insanın bu hali, diğer insanlara da bir ön yargı sebebi olacağı gibi, aksi durum ise iyi bir referans olacaktır.

$\mathrm{Bu}$ aşamada, hem davetçinin kendisine, hem de onun etrafında bulunan insanlara görev düşmektedir. Davetçi, yaşantısıyla bu saygıyı hak etmeye çalıșmalı, etrafındakiler ise ona layık olduğu saygıyı göstermelidir. Hz. Peygamber ve ashâbı, bu noktada da bizlere güzel örnekler sunmaktadır. Nitekim Racî’ olayı sonrasında müşriklerin eline esir düșen ve biraz sonra șehit edilecek olan Hubeyb b. Adiyy'e "Hayatının kurtulmasına karşılık senin yerinde Peygamberinin olmasını ister miydin?" diye sordukları zaman o, "Asla! O’nun burada benim yerime ölmesi şöyle dursun, mübârek ayaklarına bir dikenin batmasına bile gönlüm razı olmaz!" diyerek karşllık vermiştir. Bu cevaba hayret eden Ebû Süfyân ise, "Ben dünyada Muhammed kadar arkadaşları tarafından sevilen başka hiçbir kimse görmedim!” demekten

\footnotetext{
37 Nahl 16: 125.

38 Buharî, İlim, 11.

39 Âl-i İmrân 3: 159.
} 
kendini alamamıştır. ${ }^{40}$ Aynı şekilde Uhud savaşında Talha b. Ubeydullah'ın, Rasûlullah'ın etrafında sergilediği fedakârlıklar da ashâbın, Hz. Peygamber'e duyduğu saygı ve sevginin bir diğer örneğini sunmaktadır. Öyle ki, müşriklerin Rasûlullah'ın dört tarafını sardıkları sırada, Hz. Talha sağa sola dönerek kılıcıyla onları uzaklaştırmaya çalışıyordu. Bir ara, müşriklerin keskin nişancı okçularından Mâlik b. Züheyr, Hz. Peygamber'e nişan alıp bir ok atmış, Hz. Talha, bu okun ona isabet edeceğini anlayınca, buna mani olmak için, elini oka hedef tutmuş ve ok, parmağını delip, elini çolak yapmıştır. ${ }^{41}$

\section{Mucizeler ve Tebliğdeki Yeri}

Hz. Peygamber, "Hiç bir peygamber yoktur ki ona beşerin mağlup olarak inandığı bir mucize verilmiş olmasın"42 buyurmaktadır. Dolayısıyla mucize, peygamberlerinin peygamberliğini desteklemek için Allah Teâlâ'nın, onların elleriyle gerçekleştirdiği olağanüstü olaylardır.

Tabii ki Hz. Peygamber'in en büyük mucizesi Kur'ân-ı Kerim'dir. Ancak bununla birlikte zaman zaman farklı türden mucizeler gösterdiğine de şahit olunmuştur. Zira mezkûr rivâyette geçen olay da bu türden bir mucizedir. Ümmü Ma'bed'in anlattığına göre süt vermesi mümkün olmayan bir keçiden, Rasûlullah'ın duasıyla bol miktarda süt çıkmıştır.

Şüphesiz ki mucizeler, muhatap üzerinde önemli etkiler bırakmaktadır. Ancak şurası da unutulmamalıdır ki mucizeler, muhatapların aklından çok duygularını harekete geçirmektedir. $\mathrm{Bu}$ noktadan hareketle insanların, diğer mucizelerden ziyade Kur'an mucizesine öncelik vermesi gerekmektedir. Nitekim Yüce Allah, "Dediler ki: "Bize kendi Rabbinden bir âyet (mucize) getirmesi gerekmez miydi?" Onlara önceki kitaplarda açık belgeler gelmedi mi?"43 buyurmaktadır.

Kur'ân'daki bazı âyetler, inanmak istemeyen çoğu muhatabın, Peygamberlerden israrla mucize istediklerini zikretmektedir. Ancak bununla birlikte onların samimiyetsiz olduklarını ve mucize görseler dahi inanmayacaklarını da ifade etmektedir. Bu sebeple Yüce Allah, sonunda helak söz konusu olduğu için bu mucize taleplerine olumsuz karşılık vermiştir. İsrâ sûresinin 59. âyeti, bu hususu şu şekilde ifade etmektedir:

"Bizi âyet (mucize)ler göndermekten, öncekilerin onu yalanlamasından başka bir şey alıkoymadı. Semûd'a dişi deveyi görünür (bir mucize) olarak gönderdik, fakat onlar bununla (onu boğazlamakla) zulmetmiş oldular. Oysa biz âyetleri ancak korkutmak için göndeririz." 44

Ahmet Önkal, "Rasûlullah'ın İslâm'a Davet Metodu” adlı eserinde şu ifadelere yer vermek suretiyle konuya makul bir yaklaşım sergilemiştir:

40 İbn-i Sa'd, et-Tabakât, II, 42.

${ }^{41}$ Vâkıdî, Muhammed b. Ömer b. Vâkıd es-Sehmî, el-Meğâzî, 3. Baskı, thk: Mars Jons, Dâru'l-A'lemî, Beyrut 1989, I, 254.

42 Buhârî, İ'tisâm 1; Müslim, İman 239.

43 Taha 20: 133.

44 İsrâ 17: 59. 
"Münkirlerin talebi veya doğan bir lüzum ve ihtiyaç üzerine gösterilen, ani ve geçici, âfâkî ve maddî mucizeler yerine, peygamberlerin hayat, şahsiyet, seciye ve ahlakları ile tebliğ ettikleri unsurların meydana getirdikleri enfüsî mucizeler, fikir ve istidlâl, akıl ve iz'ân sahiplerinin kavraması gerekli huccet ve burhanlar çok daha önemlidir, insanların bunlara bakarak hareketleri gereklidir. Ya değilse münkirlerin devamlı isteyip durdukları akla, hayale gelmedik bir sürü maddî mucize, icrası Cenab-ı Hakk'ın kudretinde olmakla beraber, nübüvvetin mantıkî bir delili olmadığı ve gelip geçici özelliğiyle, şahit olmayanlar ve sonradan gelenler üzerinde müessiriyeti bulunmadığı için İslâm nazarında matlûb ve mahbûb sayılmamıştır." "45

$\mathrm{Bu}$ noktada tutulması gereken orta yolu ise Mazharuddin Sıddîkî şu ifadesiyle dile getirmektedir: "Sebep ve sonuç zincirinde israr etmek, Müslüman düşünür ve reformcuların başvurduğu bir şeydir; çünkü bu düşünce, insanlığın gücünü ve serbestliğini tasdik eder. Fakat katı bir sebep-sonuç sistemi, tutarlı olarak takip edildiğinde, insanın serbest iradesini tahrip edici yönde ters bir etkiye sahiptir. Benzer bir șekilde sebeplilik fikrine katı bir șekilde inanmak, insanın dinî duygularını zedeleyecek olan, kudreti sınırlı bir Allah kavramını beraberinde getirecektir." 46

Sonuç itibariyle söylemek gerekirse günümüz davetçisi, yürüttügü irşat ve tebliğ faaliyetinde, mucizelerin anlatım ve açıklanmasını da ihmal etmeden, ama ağırlığı Kur'ân'ın ilkelerine ve Hz. Peygamber'in yapmış olduğu olağan icraatlara vererek hareket etmesi gerekmektedir. Çünkü Kur'ân'ın üslûbundan da öğrendiğimiz gibi insan, hem duygusal hem de aklî yönü bulunan bir varlıktır. Dolayısıyla muhatabın hem kalbine hem de aklına hitap edilmesi gerçeği hiçbir zaman unutulmamalıdır.

\section{Sonuç ve Değerlendirme}

Şüphesiz ki Hz. Peygamber, hayatının sonuna kadar biz Müslümanlar için her konuda en güzel örnekleri sunmuştur. Bu örnekler, samimiyetle ele alındığı zaman kıyamete kadar gelecek bütün nesiller için mutluluk vesilesi olacak ilkelerdir.

Ancak onu örnek alma sürecinde Müslümanlar'ın düştüğü en büyük hata, onun örnekliğini bir bütün olarak ele almayıp, kendi ilgi ve yaklașımlarına yakın olan bölümlerle ilgilenmek suretiyle lokâl bir tavır sergilemek olmuștur. Bu çerçevede Müslümanlar'ın bir kısmı onun cihat yönüne, bir kısmı siyâsî yönüne ağırlık verirken, onun farklı yönlerine ağırlık veren Müslümanlar da bulunmaktadır. Ancak onun en çok ihmal edilen yönü ise ahlâkı olmuştur. Bu noktadaki tespitimiz, ahlakî ilkelerin bilinmesi değil uygulanması noktasındadır.

Halbuki Ümmü Ma'bed hadisine bakıldı̆̆ı zaman Rasûlullah'ın, insanları en çok etkileyen yönünün, düşmanlarının dahi takdirini kazanmış olan ahlakı olduğu görülmektedir. Zira Rasûlullah, Ümmü Ma'bed'in veciz bir şekilde ifade ettiği özellikleri sebebiyle, 23 sene gibi bir sürede Câhiliyye'nin her türlü olumsuz

\footnotetext{
45 Önkal, Ahmet, Rasûlullah'ın İslâm’a davet metodu, 23. Baskı, Kitap Dünyası Yayınları, İstanbul 2015, s. 247.

${ }^{46}$ Sıddîkî, Mazharuddin, İslâm dünyasında modernist düşünce, Dergah Yayınları, İstanbul 1990, s. 28.
} 
şartlarını yaşamış bir toplumdan, tüm insanlığa kıyamete kadar örnek olacak Asr-ı Saâdet toplumunun çıkmasına vesile olmuştur.

Hz. Peygamber, nübüvvet görevini icra ederken her ne kadar Yüce Allah tarafından mucizelerle desteklenmişse de, bu mucizeler her zaman iman sonucunu doğurmamıştır. $\mathrm{Bu}$ sebeple günümüz Müslümanlarının, “O bir peygamber idi, mucizelerle desteklenmekte idi" türünden sözlerin arkasına sığınmaksızın, onun en büyük mucizesinin Kur'ân olduğu gerçeğinden hareketle, ümmetine emanet bıraktığı Kur'ân ve Sünnet'in öğretilmesi ve yaşanmasına özen göstermesi gerekmektedir.

\section{Kaynakça}

Kurân-ı Kerîm ve Açıklamalı Meâli, 8. Baskı, Hayrettin Karaman vd., TDV Yayınları, Ankara 2010.

Âcurrî, Ebûbekir Muhammed b. Hüseyin b. Abdullah, eş-Şerîa, 2. Baskı, thk: Abdullah b. Ömer b. Süleyman ed-Demîcî, Dâru'l-Vatan, Riyâd 1999.

Beğavî, Ebû Muhammed el-Hüseyn b. Mes'ûd b. Muhammed, Şerhu's-Sünne, 2. Baskl, thk: Şuayb elArnaût, Muhammed Züheyr eș-Şâvîs, el-Mektebü'l-İslâmî, Dımașk, Beyrut 1983.

Belâzurî, Ahmed b. Yahyâ b. Câbir b. Dâvud, Cümel min ensâbi'l-eşrâf, 1. Baskı, thk: Süheyl Zekkâr, Riyâd ez-Ziriklî, Dâru'l-Fikr, Beyrut 1996.

Beyhakî, Ahmed b. Hüseyn b. Ali b. Musâ, es-Sünenü'l-kübrâ, 3. Baskl, thk: Muhammed Abdulkâdir Atâ, Dâru'l-Kütübi'l-İlmiyye, Beyrut 2003.

Bezzâr, Ebûbekir Muhammed b. Abdullah b. İbrahim, Kitâbu'l-fevâid, 1. Baskı, Hilmî Kâmil Esad Abdulhâdî, Dâru İbni'l-Cevzî, Riyâd 1997.

Buhârî, Muhammed b. İsmail Ebû Abdullah, Sahîhu Buhârî, 1. Baskı, Muhammed Züheyr b. Nâsır enNâsır, Dâru Tavkı'n-Necât, Beyrut 1422h.

Ebû Dâvûd, Süleyman İbnü'l-Eş'as b. Íshâk b. Beşîr, Sünen-i Ebû Dâvûd, thk: Muhammed Muhyiddin Abdulhamid, el-Mektebetü'l-Asriyye, Sayda-Beyrut, ty.

Ebû Ya'lâ, Ahmed b. Ali b. Müsennâ b. Yahyâ, Müsned-i Ebî Ya'lâ, 1. Baskı, Hüseyin Selim Esed, Dâru'lMe'mûn li't-Turâs, Dımașk 1984.

Eren, Mehmet, “Ümmü Ma'bed”, DİA, İstanbul, 2012, XLII, 325-326.

Hâkim en-Nîsâbûrî, Ebû Abdillâh Muhammed b. Abdillâh b. Muhammed, el-Müstedrek ale's-Sahîhayn, 1. Baskı, thk: Mustafa Abdulkâdir Atâ, Dâru'l-Kütübi'l-İlmiyye, Beyrut 1990.

Isfahânî, Ebû Nuaym Ahmed b. Abdullah, Delâilü'n-nübüvve, 2. Baskı, thk: Muhammed Ravâs Kal'acî, Abdulberr Abbâs, Dâru'n-Nefâis, Beyrut 1986.

İbn Abdilberr, Ebû Ömer Yusuf b. Abdullah b. Muhammed, el-İstîâb fî ma'rifeti'l-Ashâb, 1. Baskl, thk: Ali Muhammed el-Bicâvî, Dâru'l-Cîl, Beyrut 1992.

İbnü'l-Cevzî, Cemaluddin Ebu'l-Ferec Abdurrahman b. Ali b. Muhammed, el-Muntazam fí tarihi'l-ümem ve'l-mulûk, 1. Baskı, thk: Muhammed Abdulkâdir Atâ, Mustafa Abdulkâdir Atâ, Dâru'l-Kütübi'lİlmiyye, Beyrut 1992.

İbnü'l-Esîr, İzzuddin, Üsdü'l-ğâbe fî ma'rifeti's-Sahâbe, 1. Baskı, thk: Ali Muhammed Muavvid, Âdil Ahmed Abdulmevcûd, Dâru'l-Kütübi'l-İlmiyye, Beyrut 1994.

İbn Hacer el- Askalânî, Ebu'l-Fadl Ahmed b. Ali, el-İsâbe fî temyîzi's-Sahâbe, 1. Baskı, thk: Âdil Ahmed Abdulmevcûd, Ali Muhammed Muavvid, Dâru'l-Kütübi'l-İlmiyye, Beyrut 1415h.

İbn Hanbel, Ebû Abdullah Ahmed b. Muhammed, Fadâilu's-Sahâbe, 1. Baskı, thk: Vasiyullah Muhammed Abbâs, Müessesetü'r-Risâle, Beyrut 1983.

İbn Hişâm, Ebû Muhammed Cemâluddin, es-Sîratü'n-nebeviyye, 2. Baskı, thk: Mustafa es-Sakâ, İbrahim el-Ebyârî, Abdulhafîz eş-Șelebî, Matbaatu Mustafa el-Bâbî el-Halebî ve Evlâduhû, Mısır 1955.

İbn İshâk, Muhammed b. İshâkb. Yesâr el-Muttalibî, Sîretu İbni İshâk, 1. Baskı, thk: Süheyl Zekkâr, Dâru'l-Fikr, Beyrut 1978.

İbn Mâce, Ebû Abdullah Muhammed b. Yezîd el-Kazvînî, Sünen-i İbni Mâce, thk: Muhammed Fuad Abdulbâkî, Dâru İhyâi'l-Kütübi'l-Arabiyye-Faysal İsâ el-Bâbî el-Halebî, Beyrut, ty.

İbn Sa'd, Ebû Abdullah Muhammed b. Sa'd b. Munî' el-Hâşimî, et-Tabakâtü'l-kübrâ, 1. Baskl, thk: Muhammed Abdulkâdir Atâ, Dâru'l-Kütübi'l-İlmiyye, Beyrut 1990.

Makrızî, TakıyuddinAhmed b. Ali b. Abdulkâdir, Imtâu'l-esmâ' bimâ li'n-Nebî mine'l-ahvâl ve'l-emvâl ve'lhafede ve'l-metâ', 1. Baskı, thk: Muhammed Abdulhamid en-Nemîsî, Dâru'l-Kütübi'l-İlmiyye, Beyrut 1999. 
Müslim, İbnü'l-Haccâc Ebu'l-Hasen el-Kuşeyrî, Sahîh-u Müslim, thk: Muhammed Fuad Abdulbâkî, Dâru İhyâi't-Turâsi'l-Arabî, Beyrut, ty.

Neysâbûrî, Abdulmelik b. Muhammed b. İbrahim el-Harkûşî, Şerefu'l-Mustafa, 1. Baskı, Dâru'l-Beşâiri'lİslâmiyye, Mekke 1424h..

Önkal, Ahmet, Rasûlullah'ı́n İslâm'a davet metodu, 23. Baskı, Kitap Dünyası Yayınları, İstanbul 2015.

Sıddîkî, Mazharuddin, İslâm dünyasında modernist düşünce, Dergah Yayınları, İstanbul 1990.

Suyûtî, Abdurrahman b. Ebûbekir Celaluddin, el-Hasâisu'l-kübrâ, Dâru'l-Kütübi'l-İlmiyye, Beyrut, ty.

Süheylî, Ebu'l-Kâsım Abdurrahman b. Abdullah, er-Ravdu'l-unuf fî șerhi's-sîreti'n-nebeviyye li'bni Hișâm, 1. Baskl, thk: Ömer Abdusselâm es-Selâmî, Dâru İhyâi't-Turâsi'l-Arabî, Beyrut 2000.

Şeybânî, Ebûbekir b. Ebî Âsım, Ahmed b. Amr b. Dahhâk, el-Âhâd ve'l-mesânî, 1. Baskı, thk: Bâsim Faysal Ahmed el-Cevâbira, Dâru'r-Râye, Riyâd 1991.

Taberî, Muhammed b. Cerîr, Târihu'l-ümem ve'l-mulûk, 1. Baskı, Dâru'l-Kütübi'l-İlmiyye, Beyrut 1407.

Tirmizî, Muhammed b. İsâ b. Sevre b. Mûsâ b. Dahhâk, Sünen-i Tirmizî, 2. Baskı, thk: Ahmed Muhammed Şâkir vd., Mektebetü ve Matbaatü Mustafa el-Bâbî el-Halebî, Mısır 1975.

Vâkıdî, Muhammed b. Ömer b. Vâkıd es-Sehmî, el-Meğâzî, 3. Baskı, thk: Marsden Joney, Dâru'l-A'lemî, Beyrut 1989.

Zehebî, Şemsuddin Ebû Abdullah, Siyeru a'lâmi'n-nübelâ, 3. Baskı, thk: Şuayb el-Arnâût vd., Müessesetü'r-Risâle, Beyrut 1985.

-----, Târihu'l-İslâm ve vefeyâti'l-meşâhîr ve'l-a'lâm, 2. Baskı, thk: Ömer Abdüsselam et-Tedmurî, Dâru'lKitâbi'l-Arabî, Beyrut 1993. 